\title{
Late outcomes after interventional treatment - Successful stenting of Takayasu arteritis lesions. Single center experience in Bulgaria
}

\author{
Ivo S. Petrov, Iveta G. Tasheva, Svetlin N. Tsonev, Zoran Stankov, \\ Silvia A. Pavlova, Lachezar N. Grozdisnki \\ Department of Cardiology, Angiology and Phlebology, Acibadem City Clinic, Cardiovascular Center, University Hospital, \\ Sofia, Bulgaria
}

\section{ARTICLE INFO}

Article history:

Received: 8. 4. 2017

Received in revised form: 25. 5. 2017

Accepted: 3. 6. 2017

Available online: 12. 7. 2017

\section{Klíčová slova:}

Stenóza

Stenty

Takayasu

\section{SOUHRN}

Cíl: V naší skupině pacientů byly osoby různého věku a obou pohlaví, které byly sledovány po dobu nejméně jednoho roku. V tomto článku popisujeme endovaskulární léčbu pacientů s různě lokalizovaným onemocněním; vlastní endovaskulární přístup byl volen podle cílové léze.

Metody a výsledky: Pacienti (sedm žen a jeden muž) byli rozděleni do skupin podle Numanovy klasifikace. Sedm pacientů bylo ve věku 33 až 44 let, v jednom prŕípadě se jednalo o osobu ve věku 65 let. Pacienti byli do studie zařazováni po dobu jednoho roku. Screening pacientů s prokázanou Takayasuovou nemocí se prováděl s použitím dopplerovského ultrazvuku. Léze se nacházely na následujících místech: levá podkličková tepna (tři pacienti), pravá podklíčková tepna (jeden pacient), pravá společná karotická tepna (jeden pacient), brachiocefalický kmen (jeden pacient), horní mezenterická tepna (dva pacienti), obě zevní iliacké tepny (jeden pacient), ramus interventricularis anterior (RIA) (jeden pacient). Endovaskulárními přístupy volby byly pravý femorální, pravý radiální, levý radiální a pravý brachiální. Pro výkon byly použity balonkem expandibilní stenty, samoexpandibilní stenty, koronární lékové stenty, pouze PTA - lékem potahovaný balonek.

Závěry: $U$ všech pacientů $s$ Takayasuovou arteriitidou popsaných v našem článku byla úspěšně provedena implantace různých typů stentů. Po jednom roce nebyly zjištěny žádné významné restenózy až na jednoho pacienta, u něhož byla po šesti měsících nalezena časná restenóza.

(c) 2017, ČKS. Published by Elsevier sp. z o.o. All rights reserved.

\section{ABSTRACT}

Aim: The studied group included patients at different age and gender with follow-up period at least 1 year. The work represents endovascular treatment of patients with different localization of the disease and according to the target lesion proper endovascular access was selected.

Methods and results: The patients are divided into groups, depending on the Numano classification. Seven of studied patients were in age between 33 to 44 years, only 1 was 65 years old, 7 of them were females and one male. The patients were accumulated for the period of one year. Doppler sonography was used for screening of the patients with known Takayasu disease. Treated lesions were as follows: left subclavian artery - 3 patients, right subclavian artery -1 patient right common carotid artery - 1 patient, brachiocephalic trunk - 1 patient, superior mesenteric artery - 2 patients, both external iliac arteries -1 patient, LAD - 1 patient. Endovascular access of choice were right femoral, right radial, left radial, right brachial. The used devices were balloon expandable stents, self-expandable stents, DES/coronary, PTA only - DCB.

Conclusions: All Takayasu patients in our report were successfully treated with implantation of different types of stents. One-year results showed no significant restenosis, except in 1 patient with early restenosis until 6th month.
Keywords:

Stenosis

Stents

Takayasu 


\section{Introduction}

Takayasu arteritis (TA) is a rare chronic arteritis, affecting aorta and its branches [1]. It causes arterial stenosis/ occlusions and dilatation. We represent a case series of patients with endovascular treatment of different localization of the disease, different age, with follow-up period of up to 1 year.

The disease typically presents at less than 40 years of age. The aorta can be affected along its length and all branches can be involved, in addition to the pulmonary and coronary arteries. The most commonly affected branches are the subclavian artery and the common carotid artery. Histopathology reveals adventitial thickening, focal leukocytic infiltration of the tunica media, and intimal hyperplasia [2].

\section{Epidemiology}

The condition is most commonly seen in Japan, South East Asia, India, and Mexico [3]. Although early reports suggested that the disease was confined to females from Eastern Asia, it is now recognized worldwide and affects both sexes. Disease manifestations vary between regions [4], and women are affected in $80-90 \%$ of cases in the majority of cohorts.

Symptoms arise from both systemic inflammation and local vascular complications. The clinical manifestation varies, related to the vessels involved, including aortic arch (pulseless disease), descending thoracic or abdominal aorta, renal arteries, coronary arteries and pulmonary arteries. Initial systemic symptoms like fever, weight loss, malaise, myalgia and headaches are often missed, which leads to late diagnosis of the disease. The later pulseless phase, commonly appearing months or years later, reflects end-organ ischemia [5]. Symptoms of upper and lower limbs claudication, light headedness, and chest pain predominate.

The criteria of Ishikawa [6] consist of 1 obligatory criterion (age $<40$ years), 2 major criteria (left and right mid subclavian artery lesions) and 9 minor criteria (high erythrocyte sedimentation rate, common carotid artery tenderness, hypertension, aortic regurgitation or annuloaortic ectasia, lesions of the pulmonary artery, left mid common carotid artery, distal brachiocephalic trunk, thoracic aorta and abdominal aorta).

Establishing diagnosis of TA according to the American College of Rheumatology includes at least 3 of the following criteria: age 40 years at disease onset, claudication of extremities, decreased brachial artery pressure, blood pressure difference $10 \mathrm{~mm} \mathrm{Hg}$ between the arms, bruit over the subclavian arteries or aorta, and abnormal arteriographic results [7] and angina and/or dyspnea. Serum C-reactive protein concentration and an erythrocyte sedimentation rate are generally used in monitoring TA activity. However, these are nonspecific inflammatory markers and therefore lack sensitivity and specificity [8].

Morbidity is significant, with $23 \%$ of patients unable to work and $60 \%$ experiencing limitations in their activities of daily living [9]. Main causes of death include congestive cardiac failure, acute myocardial infarction, stro$\mathrm{ke}$, and postoperative complications [10].
The aim of the study is to evaluate the clinical outcomes after stenting of 8 patients with Takayasu disease and different vessels involvement. The follow-up period is one year with optimal medical treatment. Dual antiplatelet therapy for 12 months as well as immunosuppressive and/ or corticosteroid therapy according to the rheumatologic guidelines were chronic medical treatment of choice.

\section{Methods}

The 8 patients, described in this paper were divided into groups, depending on the Numano classification [11] as follows: Type I - branches of the aortic arch; Type lla ascending aorta, aortic arch, and its branches; Type IIb - Type Ila region plus thoracic descending aorta; Type III - thoracic descending aorta, abdominal aorta, renal arteries, or a combination; Type IV - abdominal aorta, renal arteries, or both; Type $\mathrm{V}$ - entire aorta and its branches (Fig. 1).

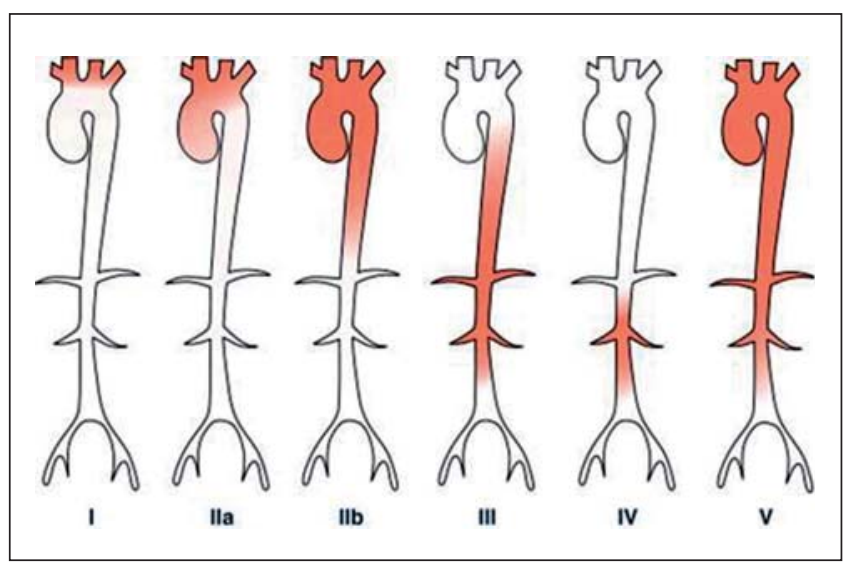

Fig. 1 - Numano classification of Takayasu arteritis (TA) [12].

Initially an ultrasound Doppler sonography was used for screening of symptomatic patients with known Takayasu disease, except one patient who was diagnosed afterwards. The following procedure was angiography and interventional treatment. The multiple lesions were treated with staged procedures.

All treated patients were followed-up at 6 month and first year with Doppler ultrasound and if occurrence of restenosis was found, a computer tomography (CT) scan was performed in a single patient.

\section{Case series}

We present here eight cases of confirmed Takayasu's arteritis patients who are not in the active phase of the disease when endovascular treatment was performed. They were all having their regular examinations with a rheumatologist and were on already established medical treatment (corticosteroids or immunosuppressors). The patients were accumulated for the period of one year. The basic details of all patients are given in the Table 1. The detailed endovascular intervention is described for each patient. 


\section{Four of the patients are classified in Type I}

Clinical case 1 - A 41-year-old woman was admitted with symptoms of dizziness and abdominal pain. Her past history revealed previous endovascular procedure - stenting of right subclavian artery and celiac trunk. The current Doppler and angiographic examination revealed instent thrombosis of right subclavian artery; left subclavian artery with $70 \%$ ostial stenosis and thrombosis of celiac trunk. With right femoral access and $6 \mathrm{Fr}$ long sheath, stenting of left subclavian artery was done with balloon expandable stent Scuba $8 / 30 \mathrm{~mm}$ (Figs. 2A and 2B). The six month Doppler follow-up showed no restenosis. No data from 1-year Doppler because the patient was lost from follow up.

Clinical case 2 - A 39-year-old woman with complaints of headache and dizziness was admitted in our hospital. Her medical history consisted of ischemic stroke (April 2014) with residual left side hemiparesis. Angiography via right radial access was done - left common carotid artery (LCCA) was found with $50 \%$ ostial stenosis; left internal carotid artery (LICA) - with $65-70 \%$ stenosis; right common carotid artery (RCCA) with $80 \%$ stenosis. Endovascular procedure was initiated with an implantation of nitinol self-expandable stent Cristallo ideale $11 / 40 \mathrm{~mm}$ in RCCA. Postdilatation with $8 / 20 \mathrm{~mm}$ balloon was done (Figs. 3A and $3 B$ ). One-year follow-up examination showed patent stent without restenosis and asymptomatic patient.
Clinical case 3 - A 33-year-old man presented in our institution with occasionally found significant difference in blood pressure of both arms (>50 $\mathrm{mmHg}$ ). Doppler sonography revealed severe stenosis of left subclavian artery. The angiography confirmed subtotal occlusion of left subclavian artery. Intervention via left radial artery was started with predilatation with $8 / 40 \mathrm{~mm}$ semi-compliant balloon and implantation of nitinol self-expandable stent Cristallo ideale 9/30 mm. Postdilatation with 9/30 mm HP balloon was performed with good final angiographic result (Figs. 4A and 4B). One year later ultrasound showed patent stent in left subclavian artery.

Clinical case 4-A 36-year-old female with multiple syncopes, dizziness, headache, weakness and pain in the left arm was admitted for diagnostic imaging and treatment. The first angiography correlated with ultrasound findings - LCCA - with ostial occlusion; left subclavian artery - with proximal occlusion; brachiocephalic trunk - with 99\% ostial stenosis; right subclavian artery - with thrombosis. Intervention of brachiocephalic trunk - the only artery, supplying the brain, was initiated. A 6 Fr long sheath was introduced in right femoral artery towards brachiocephalic trunk: predilatation with balloon $4 / 40 \mathrm{~mm}$ was followed by implantation of nitinol self-expandable stent Cristallo ideale $11 / 40 \mathrm{~mm}$ and postdilatation with 5.5/20 $\mathrm{mm}$ balloon (Figs. 5A and $5 \mathrm{~B}$ ). A planned recanalization of left subclavian artery one month later was undergone

\begin{tabular}{|c|c|c|c|c|c|c|c|}
\hline Age & Sex & Symptoms & Lesions & $\begin{array}{l}\text { Vascular } \\
\text { access }\end{array}$ & $\begin{array}{l}\text { Endovascular } \\
\text { treatment }\end{array}$ & $\begin{array}{l}\text { Early } \\
\text { restenosis } \\
\text { up to 6th } \\
\text { month }\end{array}$ & $\begin{array}{l}\text { 1-year } \\
\text { follow-up } \\
\text { restenosis }\end{array}$ \\
\hline 41 & Female & Dizziness, abdominal pain & Left subclavian artery & Femoral & $\begin{array}{l}\text { Balloon-expandable } \\
\text { nitinol stents }\end{array}$ & No & No \\
\hline 39 & Female & Ischemic stroke & RCCA & Radial & $\begin{array}{l}\text { Self-expandable } \\
\text { nitinol stents }\end{array}$ & No & No \\
\hline 33 & Male & $\begin{array}{l}\text { Difference in arm blood pressure, } \\
\text { vertigo left subcl. artery }\end{array}$ & Left subcl. artery & Radial & $\begin{array}{l}\text { Self-expandable } \\
\text { nitinol stent }\end{array}$ & No & No \\
\hline 36 & Female & $\begin{array}{l}\text { Dizziness, headache, weakness, } \\
\text { pain in left arm }\end{array}$ & $\begin{array}{l}\text { Brachiocephalic trunk } \\
\text { Left subclavian artery }\end{array}$ & Femoral & $\begin{array}{l}\text { Self-expandable } \\
\text { nitinol stent } \\
\text { Balloon-expandable } \\
\text { nitinol stent }\end{array}$ & $\begin{array}{l}\text { No } \\
\text { Yes in-stent } \\
\text { restenosis } \\
\text { (treated } \\
\text { with DCB) }\end{array}$ & $\begin{array}{l}\text { No } \\
\text { No }\end{array}$ \\
\hline 34 & Female & Abdominal pain & Celiac trunk & Radial & $\begin{array}{l}\text { Balloon-expandable } \\
\text { nitinol stent }\end{array}$ & No & No \\
\hline 43 & Female & Abdominal pain & $\begin{array}{l}\text { Celiac trunk, superior } \\
\text { mesenteric artery }\end{array}$ & Radial & $\begin{array}{l}\text { Balloon-expandable } \\
\text { nitinol stents }\end{array}$ & No & No \\
\hline 44 & Female & Claudication & Right and left AIE & Brachial & $\begin{array}{l}\text { Self-expandable } \\
\text { nitinol stent }\end{array}$ & No & No \\
\hline 65 & Female & $\begin{array}{l}\text { Headache, dizziness, chest } \\
\text { pain }\end{array}$ & $\begin{array}{l}\text { Right subcl. artery, } \\
\text { LAD }\end{array}$ & Radial & $\begin{array}{l}\text { Self-expandable } \\
\text { nitinol stent, } \\
\text { Coronary DES }\end{array}$ & No & No \\
\hline
\end{tabular}

AIE - arteria iliaca externa; DCB - drug coated baloon; DES - drug eluting stent; LAD - left anterior descending artery; PTA - percutaneous transluminal angioplasty; RCCA - right common carotid artery. 

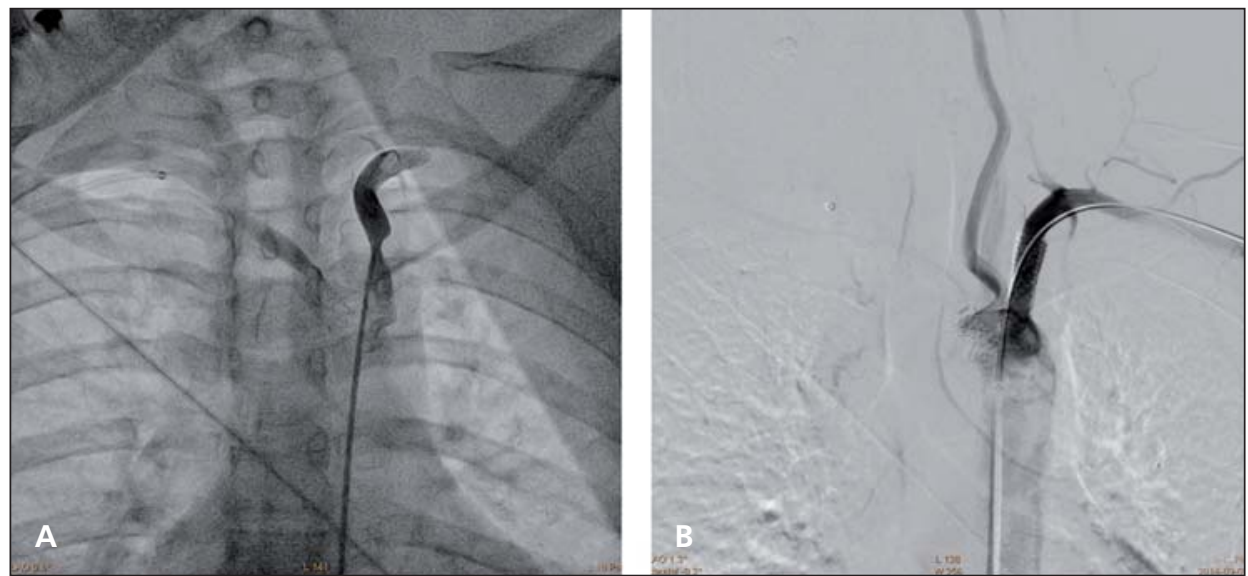

Fig. 2 - Severe stenosis of left subclavian artery (A) and stenting of left subclavian artery (B).

with right femoral access and $6 \mathrm{Fr}$ long sheath, placed in aortic arch. Terumo wire and $4 \mathrm{Fr}$ microcatheter were used, predilatation with $5 / 80 \mathrm{~mm}$ balloon and balloon expandable stent Scuba $6 / 55 \mathrm{~mm}$ was implanted. Five months later a control angiography showed patent stent in brachiocephalic trunk and $90 \%$ instent restenosis in left subclavian artery.

Percutaneous transluminal angioplasty (PTA) with HP balloon 5/40 $\mathrm{mm}$ and drug eluting balloon (DCB) In.Pact $6 / 60 \mathrm{~mm}$ was performed. One year later the ultrasound showed patency of both stents.

\section{Two of the patients are classified in Type III}

Clinical case 5 - A 34-year-old woman with complaints of abdominal pain and Doppler data for severe stenosis of celiac trunk was hospitalized for endovascular treatment. Angiography via right radial artery revealed $90 \%$ ostial stenosis of celiac trunk (Figs. 6A and 6B). Predilatation with $4 / 20 \mathrm{~mm}$ balloon was performed and implantation of balloon-expandable stent Racer 6/18 mm. Follow-up was done 1 year later, showing patent stent.

Clinical case 6 - A 43-year-old woman with abdominal angina and Doppler data of severe stenosis of superior mesenteric artery and celiac trunk was admitted in an- giology department. An angiography via right radial artery showed $80 \%$ ostial stenosis of celiac trunk and $70 \%$ stenosis of superior mesenteric artery. Predilatation with balloon $5 / 20 \mathrm{~mm}$ was done, followed by implantation of balloon-expandable stent Radix $6 / 17 \mathrm{~mm}$ in superior mesenteric artery. Direct stenting of celiac trunk with balloon-expandable stent Radix 7/17 mm was done. One-year follow-up with CT scan revealed patent stents with good flow and minimal instent proliferation.

\section{One patient is classified in Type IV}

Clinical case 7 - A 44-year-old woman presented with 50 $m$ claudication in both legs. Doppler sonography and angiography showed thrombosis of right iliac external artery and $90 \%$ stenosis of left iliac external artery. Brachial access, 6 Fr long sheath, Terumo 0.35 stiff wire and 4 Fr microcatheter were used for recanalization of right iliac external artery. Predilatation with balloons $4 / 80 \mathrm{~mm}$ and $5 / 40 \mathrm{~mm}$ was done, followed by implantation of self-expandable Protege stent 7/120 $\mathrm{mm}$ with restored blood flow. Planned PTA of left iliac external artery after 1 month was performed - predilatation with balloons $5 / 80$ and $6 / 80 \mathrm{~mm}$; implantation of Protege $8 / 60 \mathrm{~mm}$ stent and postdilatation with $6 / 80 \mathrm{~mm}$ balloon. Follow-up 1 year later with $\mathrm{CT}$

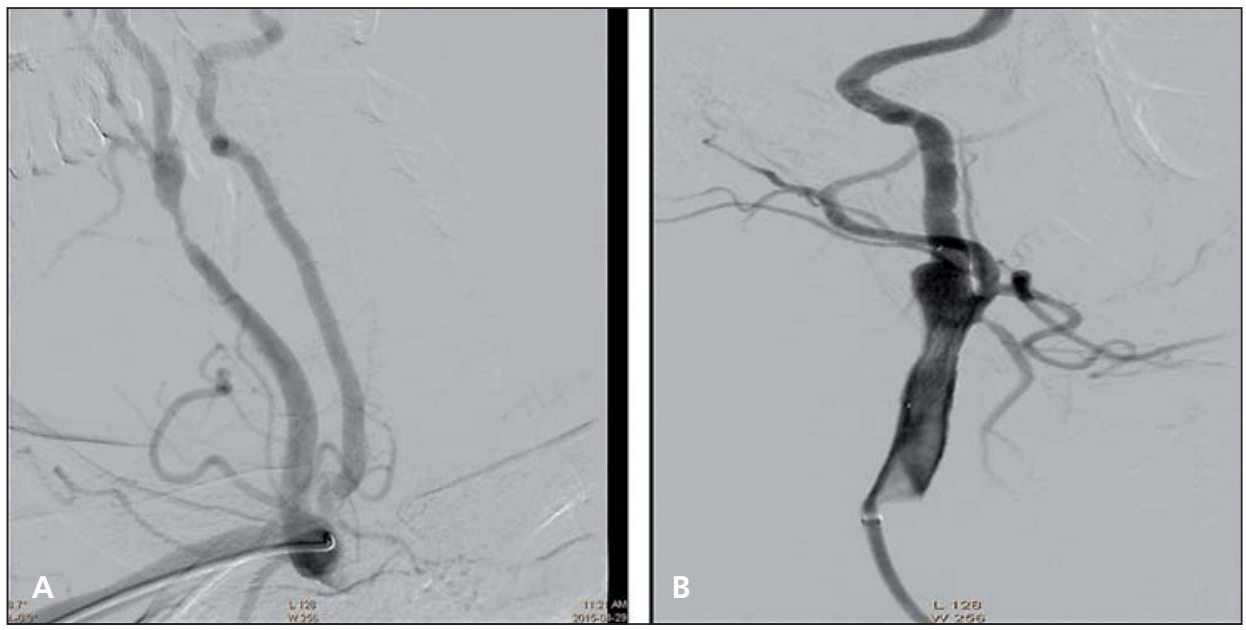

Fig. 3 - Severe stenosis of RCCA (A) and after stenting of RCCA (B). 


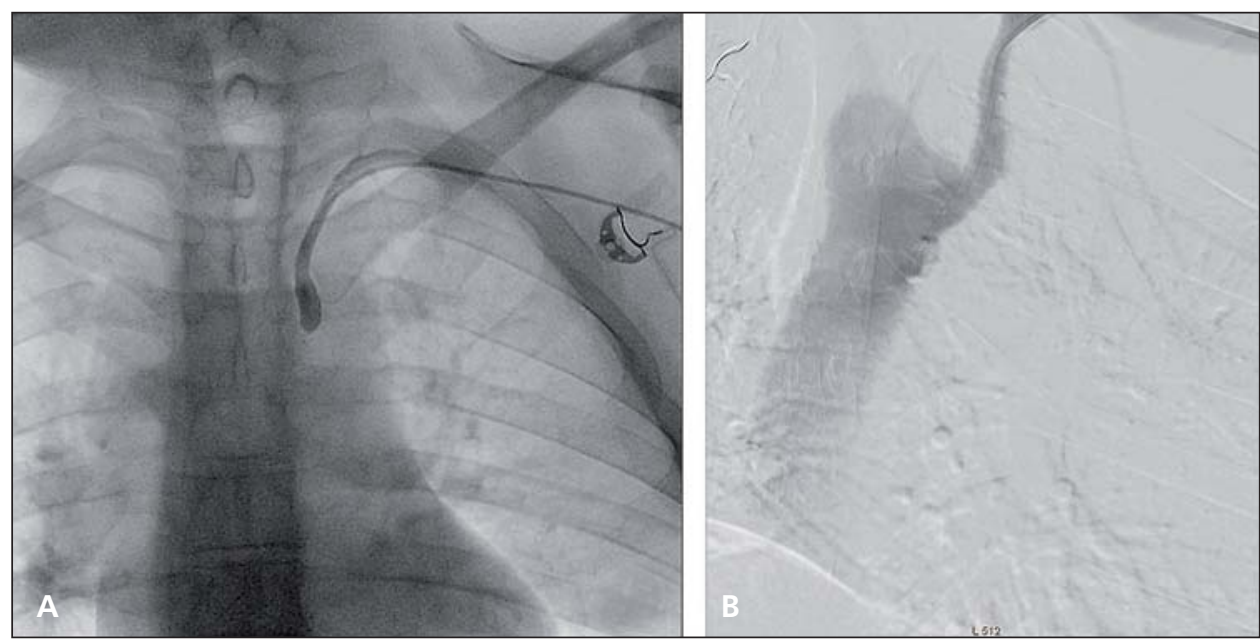

Fig. 4 - Subtotal occlusion of left subclavian artery (A) and after stenting of left subclavian artery (B).

scan was done, showing patent iliac stents (Fig. 7) and new significant stenosis of celiac trunk. Transradial access was used for endovascular treatment of the $90 \%$ ostial stenosis with predilatation and implantation of Hippocampus stent $6.5 / 20 \mathrm{~mm}$. A few months later the patient was with recurrent claudication in the right leg. A new angiography was performed, showing $80 \%$ de novo stenosis of right iliac common artery. Balloon dilatation with DCB balloon 8/30 $\mathrm{mm}$ was done with excellent angiographic result. Ultrasounds follow-up 1 year after the last procedure showed patent stents, no residual stenosis and no de novo lesions. The patient was asymptomatic.

\section{One patient is classified in Type $V$}

Clinical case 8-65-year-old woman, complaining of headache, dizziness and chest pain was diagnosed with significant stenosis of right subclavian artery and was referred for coronary and peripheral angiography, which showed one coronary vessel disease; left anterior descending artery (LAD) $-80 \%$ stenosis in the middle segment and $90 \%$ stenosis of right subclavian artery. PTA of right subclavian artery was performed by right radial access: predilatation with 5/40 mm balloon, implantation of stent Protege 9/40 $\mathrm{mm}$ and postdilatation with $6 / 40 \mathrm{~mm}$ balloon (Figs. $8 \mathrm{~A}$ and $8 B$ ). At the same procedure stenting of LAD with zotarolimus eluting stent Resolute $3 / 18 \mathrm{~mm}$ was performed. Six months later the patient represented with abdominal pain and Doppler data of stenosis of superior mesenteric artery. Endovascular treatment with implantation of balloon-expandable Racer $6 / 12 \mathrm{~mm}$ stent and postdilatation with 7/20 mm balloon, was done. One-year follow-up showed patent stent of subclavian and mesenteric arteries and no cardiac complaints with negative stress test.

\section{Discussion}

It is considered that TA is a rare disease with clinical heterogeneity across different ethnic groups. There is few data among Balkans population. Nevertheless, Karageorgaki and his group studied 42 patients from 4 large referral centers in Greece. The authors conclude that TA in Greece clinically and epidemiologically resembles the pattern of disease in Japan and the Western he-

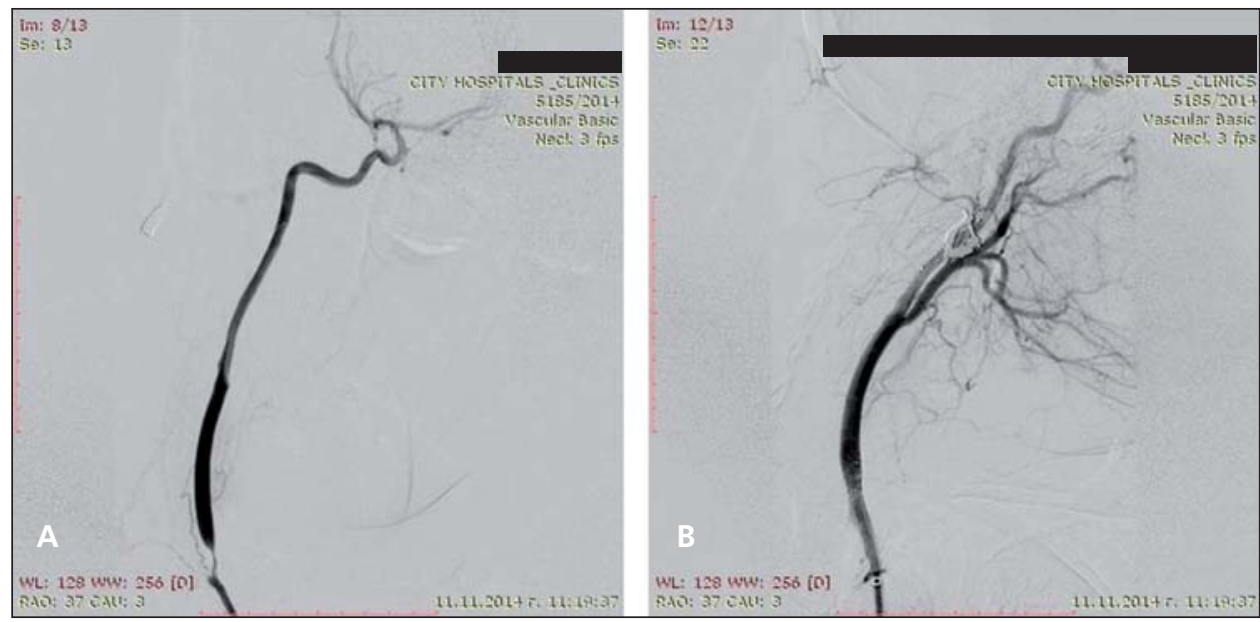

Fig. 5 - Brachiocephalic trunk - $99 \%$ ostial stenosis (A) and after stenting of brachiocephalic trunk (B). 


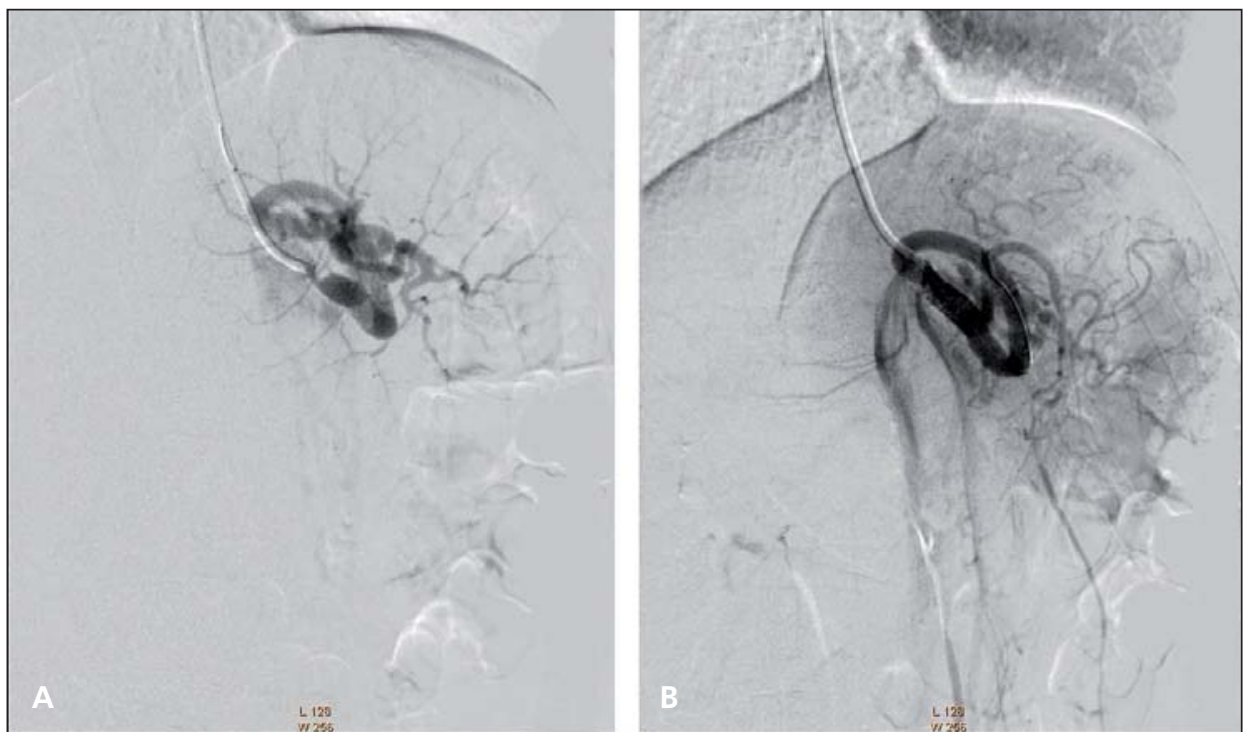

Fig. 6 - Ostial stenosis of celiac trunk $90 \%$ (A) and after stenting of celiac trunk (B).

misphere [12]. A research group from Turkey included even larger cohort of TA patients: 248 patients. The results are similar and authors conclude that the demographical, clinical and angiographic findings of TA patients in Turkey were similar to those reported from Japan, Brazil and even Colombia [13]. In Bulgaria there is no published data about Takayasu patients, although these patients are usually diagnosed and treated in rheumatology clinics. According to the literature, open surgical treatment remains superior to endovascular intervention in the treatment of long and irregular TA lesions, although sometimes surgical reconstruction is difficult because of extensive fibrosis and adhesions of peri-arterial tissues. Takayasu lesions in aortic branch vessels are frequently ostial or proximal and can be stented with feasibility. Good results are seen in the treatment of short focal stenosis in the presence of inactive disease.

Percutaneous intervention with stent implantation is feasible choice for stenosis and occlusion of carotid arteries as well as peripheral lesions and is increasingly used for the management of Takayasu arteritis. A clinical trial among Indian population with one hundred and forty-three (143) consecutive patients with Takayasu arteritis involving aorta and carotid and subclavian arteries were treated by endovascular intervention. The results showed that endovascular treatment is feasible, safe and efficacious. Multiple lesions and multiple vessels can be treated at the same time. Stents have improved the results although drug-eluting and cutting balloons have also been used successfully. There have been several long term studies of using balloon angioplasty without stent implanta-

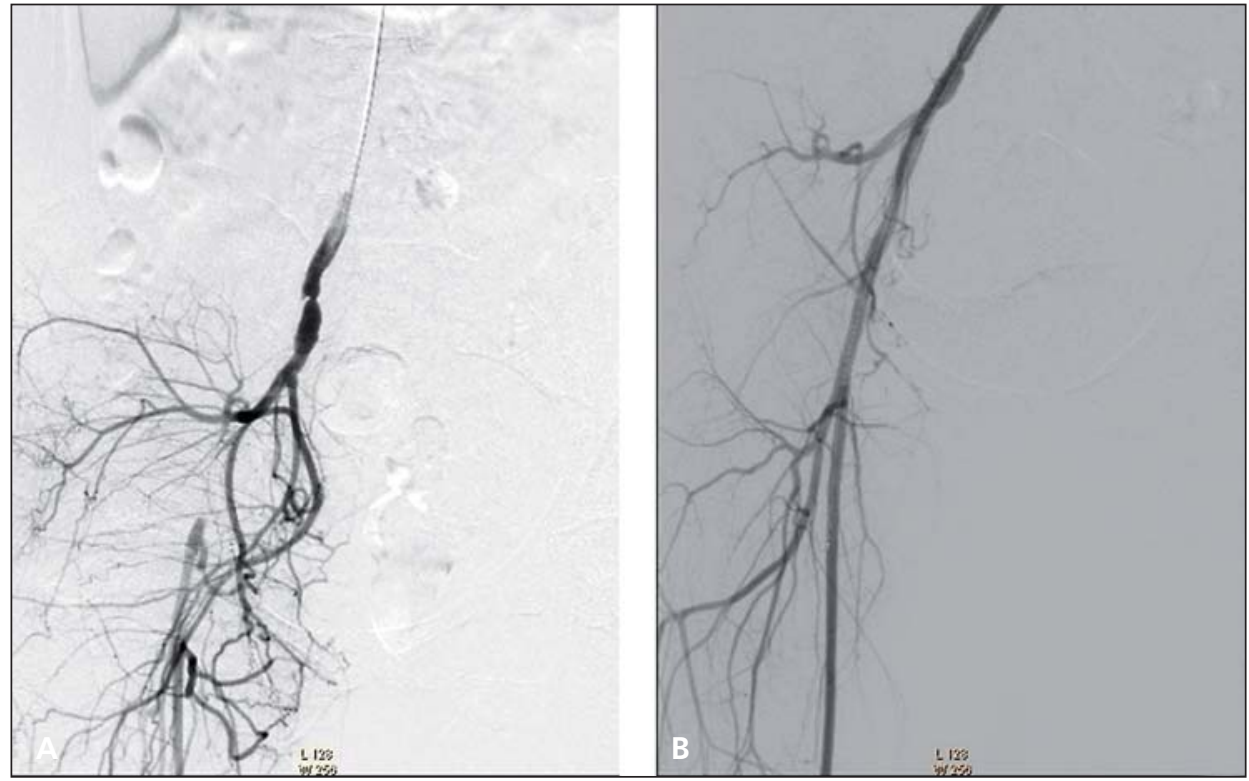

Fig. 7 - Occlusion of right external iliac artery (A) and after recanalization and stenting (B). 


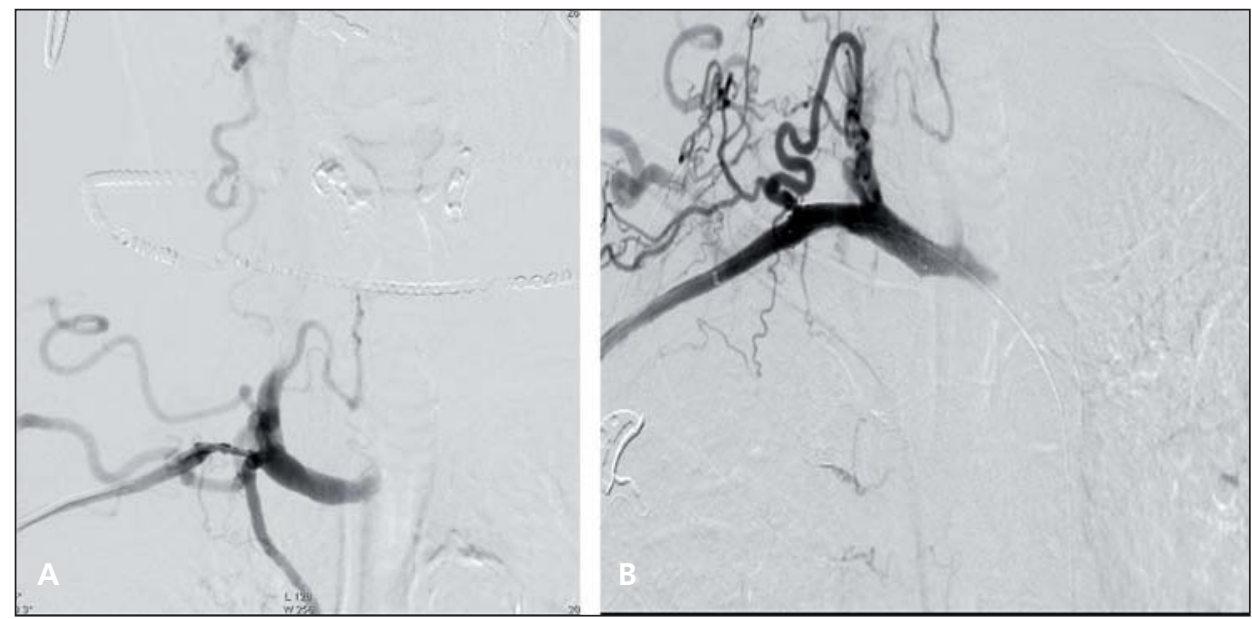

Fig. 8 - Stenosis of right subclavian artery $90 \%$ (A) and after stenting of right subclavian artery (B).

tion. A restenosis rate with angioplasty is up to $20 \%$ with initial success rate over $85 \%$. Angioplasty with stent implantation has a restenosis rate closer to $10 \%$ and success rate approaching 100\% $[14,15]$. Endovascular treatment of symptomatic TA has been found to be safe and very effective with an acceptable 30-day complication rate of $7.1 \%$ as reported by Wrotniak et al according to the recent studies data [16]. However, it has been shown that in-stent stenosis remains the main issue in both the surgical and the endovascular approach $[17,18]$. Stenting is considered to be a better choice, compared to plain balloon dilatation in rigid ostial lesions. Besides typical instent stenosis, external stent compression by progressive vessel wall fibrosis and calcification has been described [19]. It is necessary to use a different management for the various types of restenosis (whether instent hyperplasia or external compression), according to the new endovascular devices.

\section{Conclusion}

Current study presents first results from single Bulgarian center including interventionally treated patients with Takayasu disease. Despite the small number of patients there is big variety of type and lesion localizations. The proper choice of the vascular access was of great importance for the successful treatment of the target lesions. The overall short- and long-term results are beneficial except in one lesion in 1 patient. As result we can conclude that endovascular interventions are now emerging a treatment of choice, but further studies are needed.

Impact on daily practice: TA disease patients could be successfully treated with endovascular procedures with good long-term results. In Bulgaria, this disease is often misdiagnosed and more careful and focused clinical approach among young patients is needed. A better collaboration with rheumatologists could result in earlier diagnosis of the vascular lesions. A multidisciplinary approach to the diagnosis and management of Takayasu arteritis patients is essential to achieve satisfactory patient outcomes.

\section{Conflict of interest}

None declared.

\section{Funding body}

None.

\section{Ethical statement}

I declare, on behalf of all authors, that the research was conducted according to Declaration of Helsinki.

\section{Informed consent}

I declare, on behalf of all authors, that informed consent was obtained from all patients participating in this study.

\section{References}

[1] F. Numano, Y. Kobayashi, Takaysau arteritis - beyond pulselessness, Internal Medicine 38 (1999) 226-232.

[2] M. Hotchi, Pathological studies on Takayasu arteritis, Heart and Vessels 7 (1992) 11-17.

[3] S.L. Johnston, R.J. Lock, M.M. Gompels, Takayasu arteritis: a review, Journal of Clinical Pathology 55 (2002) 481-486.

[4] R. Moriwaki, M. Noda, M. Yajima, et al., Clinical manifestation of Takayasu arteritis in India and Japan - new classification of angiographic findings, Angiology 48 (1997) 369-379.

[5] G.S. Kerr, C.W. Hallahan, J. Giordano, Takayasu arteritis, Annals of Internal Medicine 120 (1994) 919-929.

[6] K. Ishikawa, Diagnostic approach and proposed criteria for the clinical diagnosis of Takayasu arteriopathy, Journal of the American College of Cardiology 12 (1988) 964-972.

[7] W.P. Arend, B.A. Michel, D.A. Bloch, The American College of Rheumatology 1990 criteria for the classification of Takayasu arteritis, Arthritis and Rheumatism 33 (1990) 1129-1134.

[8] G.S. Hoffman, A.E. Ahmed, Surrogate markers of disease activity in patients with Takayasu arteritis: a preliminary report from the International Network for the Study of the Systemic Vasculitides (INSSYS), International Journal of Cardiology 66 (1998) S191-S194.

[9] K. Maksimowicz-McKinnon, T.M. Clark, G.S. Hoffman, Limitations of therapy and a guarded prognosis in an American cohort of Takayasu arteritis patients, Arthritis and Rheumatism 56 (2007) 1000-1009.

[10] K. Ishikawa, S. Maetani, Long-term outcome for 120 Japanese patients with Takayasu's disease: clinical and statistical analyses of related prognostic factors, Circulation 90 (1994) 1855-1860. 
[11] A. Hata, M. Noda, R. Moriwaki, F. Numano, Angiographic findings of Takayasu arteritis: new classification, International Journal of Cardiology 54 (1996) S155-S163.

[12] Z.T. Karageorgaki, G.K. Bertsias, C.P. Mavragani, et al., Takayasu arteritis: epidemiological, clinical, and immunogenetic features in Greece, Clinical and Experimental Rheumatology 27 (2009) S33-S39.

[13] M. Bicakcigil, K. Aksu, S. Kamali, Takayasu's arteritis in Turkey - clinical and angiographic features of 248 patients, Clinical and Experimental Rheumatology 27 (2009) S59-S64.

[14] T. Miyata, O. Sato, H. Koyama, et al., Long-term survival after surgical treatment of patients with Takayasu's arteritis, Circulation 108 (2003) 1474-1480.

[15] A. Perera, T. Youngstein, R. Gibbs, et al., Optimizing the outcome of vascular intervention for Takayasu arteritis, British Journal of Surgery 101 (2014) 43-50.
[16] L. Wrotniak, A. Kabłak-Ziembicka, T. Przewłocki, et al., Long-term experience in patients undergoing endovascular revascularization procedures for symptomatic Takayasu arteritis, Journal of Rare Cardiovascular Diseases 1 (2013) 8-13.

[17] D. Saadoun, M. Lambert, T. Mirault, et al., Retrospective analysis of surgery versus endovascular intervention in Takayasu arteritis: a multicenter experience, Circulation 125 (2012) 813-819.

[18] N. Horie, K. Hayashi, M. Morikawa, et al., Restenosis after endovascular PTA/stenting for supra-aortic branches in Takayasu aortitis: report of three cases and review of the literature, Acta Neurochirurgica (Wien) 153 (2011) 1135-1139.

[19] M. Spacek, P. Zimolova, J. Veselka, Takayasu arteritis: use of drug-eluting stent and balloon to treat recurring carotid restenosis, Journal of Invasive Cardiology 24 (2012) E190-E192. 